UDC 322(4) ; 342.731(4)

CERIF: S140

Velizar Mirčov, LLM*

Ivica Mladenović, LLM**

\title{
TYPES OF RELATIONSHIPS BETWEEN THE STATE, RELIGION AND RELIGIOUS ORGANIZATIONS IN EUROPE - AN ATTEMPT TO DEVELOP A NEW CLASSIFICATION
}

Existing theorethical models of relationship between the state and religious organisations is under consideration in this article. European countries have implemented different legal/legislative solutions which are used for regulating the relationships between the state, religion and religious organisations. Many authors have classified these different types of regulations in a number of ideal types. Within the context of this paper a new type of classification which is based on two separate dimensions of the relationship towards religion and religious organisations is present$e d$. The first dimension is intimately interlinked with the laicisation of the state, whilst the second one is linked with its secularistion. These dimensions are measured by an in depth study of a number of variables. Data based on the analysis of legislations within 19 European countries are presented herein within our classificatory scheme. This article can be a starting point for further theoretical and empirical work within this particular subfield.

Key words: $\quad$ Church and state. - Religious organisation. - Laicisation. - Secularisation. yahoo.com.

* PhD candidate at the University of Belgrade Faculty of Philosophy, velizarx@

** PhD candidate at the University of Belgrade Faculty of Philosophy, ivicamladenovic@gmail.com. 


\section{INTRODUCTION}

The relationship between the church and state within European context, and within U.S. as well, has become an important topic of research in the last twenty years. Broadly conceived, relationships between the church and the state can be perceived from the angle of view of a number of scientific disciplines: law, history, sociology, political science, and so on. The aim of this work is to offer a more reliable empirical basis for the classification of model of the relationship of the state and religious organisations in Europe by using comparison of legal regulation of church-state relations in 19 counties as a methodological tool. A number of authors have developed various models for the classification of the relationship between the church and the state in the past. ${ }^{1}$ Passages below will analyze the advantages and shortcomings of the existing theoretical models and offer a proposition for a new classification, as well as arguments on why exactly this proposition is instrinsically preferable to other models.

The first part of the text will present the most important areas that are regulated by church-state law. Later, theoretical models of other authors will be analyzed that deal with the issue of the relationship between the state and religious communities, and then the theoretical basis of our comparative research will be presented. Within the fourth part, we will present the methodology with the aid of which we conducted comparative research of the modes of relationship of the state and religious organizations, and we will present the research results in addition to this. At the very end, we will examine critically the extent to which the results of our research fit within the presented theoretical model.

1 S. Monsma, C. Soper, The Challenge of Pluralism, Rowman \& Littlefield Publishers, Lanhman 2009; A. Stepan, "The Multiple Secularism of Modern Democratic and Non-Democratic Regimes", Rethinking Secularism (ed. C. Calhoun), Oxford University Press, New York 2011; S. Avramović, Prilozi nastanku državno-crkvenog prava u Srbiji, Službeni glasnik, Beograd 2007; S. Ferrari, "The Emerging Pattern of Church and State in Western Europe: The Italian Model”, BYU Law Review 2/1995, 421-437; M. Minkenberg, "The Policy Impact of Church-State Relations: Family Policy and Abortion in Britain, France, and Germany", Church and State in Contemporary Europe (ed. J. Madeley), Frank Cass, London 2005; M. Chaves, E. D. Cann, "Regulation, Pluralism, and Religious Market Structure. Explaining Religion's Vitality", Rationality and Society 4/3/1992, 27290; V. Bader, "Religions and States. A New Typology and a Plea for Non-Constitutional Pluralism", Ethical Theory and Moral Practice 6/2003, 55-91; J. Madeley, "European Liberal Democracy and the Principle of State Religious Neutrality", Church and State in Contemporary Europe (ed. J. Madeley), Frank Cass, London 2005b; J. Martinez-Torron, C. Durham, "Religion and the Secular State / La Religion et l'État laïque: Interim Reports, General Rapporteurs" Religion and the Secular State / La Religion et l'État laïque: Interim Reports (ed. C. Durham), International Center for Law and Religion Studies 2010, 1-56; J. Fox, "World Separation of Religion and State in the 21st Century", Comparative Political Studies 5/2006, 537-569. 


\section{THE AREAS THAT ARE REGULATED BY THE CHURCH-STATE LAW}

Broadly speaking, when studying the relationships between the church and religious communities a number of theoretical models can be employed, whilst it is worth mentioning that within social sciences the most useful and the most frequently employed are historical and that belonging to sociology and political science. Historical methods offer a framework for understanding and explanation of the historical development of politics, religion and religious organisations, most frequently within a particular state. Socio-political model helps us understand the way state and religious organisations have impact on other spheres of life: culture, politics, ideology, family, economy and so on. Wihin this particular segment we wish to focus our attention on an important field of study, as well as answer a particular question: how are the principles of laicisation and secularisation of the state, i.e. the processes of the final division of authority between the religious organisations and the state, implemented within the legal systems of various state systems? Sima Avramović ${ }^{2}$ argues persuasively that three major principles should be borne in mind when considering the relationship between the state and the religious organizations: 1. Religious freedoms (with an emphasis on corporate freedoms); 2. Neutrality of the state (the division of authority between the state and religious organizations); 3 . The principle of equality of religious organizations. As a starting point, it is essential that we define what the division between the state and the religious organizations implies.

The above mentioned separation between church and state in essence has two important aspects. On the one hand, the state is divided from religious organization from the legal point of view, which practically means: the state is divided/independent from religious authority; there is no official church; all departments of the government and the local government are not connected to any religion, not even symbolically; religion does not interfere in key political questions; political parties are not close to religions, churches or church authorities; the laws are enacted irrespective of the attitudes of religious organizations towards them. ${ }^{3}$ On the other, this division means that the state does not interfere in the internal matters of the religious organisations and treats all of the religious organisations equally. In that sense, the separation of the religious organisations from the state rests on a number of key assumptions and these are: all religious organizations have the same status; the government and

2 S. Avramović, 98.

3 B. Basdevant-Gaudemet, F. Messner, Les origines historiques du statut des confessions religieuses dans les pays de l'Union européenne, Presses Universitaires de France, Paris 1999; J. Francis, "The Evolving Regulatory Structure of European Church-State Relationships", Journal of Church and State 1992, 775-804. 
parliament do not make decisions that impact the internal organization and the functioning of the church; the state (monarch, government and parliament) does not influence the establishment of church hierarchy; religious education/catechism is not controlled by the state; church law is independent from the state law; religious organizations are free to define their teaching and beliefs without any state involvement. ${ }^{4}$

Within our particular analysis, we will study both of these mentioned aspects. It is important to add that the analysis of primary data will focus on formal and legal solutions that particular states have adopted to define the relationship between the state and religious organizations within a specific context (for some areas actual implementation of the legal solutions within the current legal practice will be taken into account). Legal regulation that defines the relationships between the state, religion and religious organizations is mainly located in the part of law that is labeled as church and state law. This law regulates a number of important questions in each particular state.

\section{THEORETICAL MODELS OF THE RELATIONSHIP BETWEEN THE RELIGIOUS ORGANIZATIONS AND THE STATE}

The most simple approach to the classification of the relationship between the religious organizations and the state is the one that sees them as secular or those with state (or established) church. Nonetheless, this classification studies only one variable, the existence and non existence of the state church within the Constitution, whilst the other aspects of the relationship between the church and the state are neglected. Since there is no perfect example of blending of church and state within the European context (with the exception of Vatican), and in addition to this there is no perfect example of the full division of authority of the church and the state, given classification is not applicable to any of the European states. A bit more nuanced classification is given in a book authored by Sima Avramović. One the one hand there is a model of absolute division, that exists in France, The Netherlands and Slovenia. The second model is that of the state church where the state identifies with the majority church. Leading examples here are England, Greece and a number of Nordic countries. And finally, the third model is that of the cooperative division of authority which intrinsically implies benevolent cooperation. Such a model exists in Germany, Belgium and Austria, and Italy and Spain are tending towards this model. The third model - also called cooperative separation - means that the state allows for religious organisations to

4 R. Remond, Religion et société en Europe: La sécularisation aux XIX et XX siècles 1789-2000, Seuil, Paris 2001. 
exercise certain functions that are in other countries performed exclusively by the state, that is to say, the areas of authority become intertwined. Nonetheless, Avramović rightly observes that not even this tripartite division can be an accurate depiction of the relationship between the church and the state in Europe. ${ }^{5}$

Related to this, Vukomanović ${ }^{6}$ adds a fourth model to the tripartite scheme, the model of established historical and traditional religions. Within the context of this model the state acknowledges a number of religious organisations and gives them their equal rights, while other organisations have restricted rights. Nonetheless, this expanded model can not stand for the accurate depiction of the legal solutions with regard to the development of church and state within the context of European countries.

Within their book Chalenges of Pluralism, Stephen Monsma and Christopher Soper present three models of the mentioned relationship. The first model is the division of church and state so that religion and politics are seen as distinct areas and state is neutral toward religion, and the best example of this model is the U.S. context. The second model is the model of the established church: "The state provides the church with recognition, accommodation, and often financial support; the church provides the state with an aura of legitimacy and tradition, recognition, and a sense of national unity and purpose". ${ }^{7}$ Said authors distinguish formally (constitutionally) established churches and informally established churches, which gain their status by means of state favouritism and the cultural domination that this church has in the community. The best examples of second model are England, Denmark and Norway while Germany could be perceived as a state with two informally founded churches, Catholic and Luteran. The Third model is the pluralist model. Within this model, "society is understood as made up of competing or perhaps complementary spheres". ${ }^{8}$ The domains of education, family, economy, religion and governance have special activities and responsibilities and have the autonomy to achieve them.

Alfred Stepan distinguishes three models in his analysis of secularism: separatist model of the U.S., the model of the established religion of Germany, Great Britain, Denmark and Iceland and the model of positive accomodation of the Netherlands. ${ }^{9}$ Gerhard Robbers forms a tripartite scheme of the relationships between the church and the state. According

5 S. Avramović, 107.

6 M. Vukomanović, Religija, Zavod za udžbenike i nastavna sredstva, Beograd 2004.

7 S. Monsma, 11

8 Ibid, 11

9 A. Stepan, 116. 
to his scheme, there are three basic models: the systems of state church, the systems of strict separation and the system of common goals. ${ }^{10} \mathrm{Al}$ though Monsma, Stefan and Robers label their three models differently, it is obvious that they have in mind the division similar to the tripartite model: state church - cooperative separation - separation of the church and the state.

Silvio Ferrari also distinguishes three models of church-state relationship: "The classification of church-state systems in Western Europe is traditionally based on a tripartite; they are identified variously as separation systems, concordatarian ${ }^{11}$ systems, and national church systems". ${ }^{12}$ Ferrari admits that this classification is: "overemphasizes the formal aspects of church-state relations and it does not pay enough attention to their content". ${ }^{13}$ With respect to legal regulations for registration of religious organizations Lavrič and Flere discern four major types of countries: 1) post-communist countries with very difficult and complicated registration procedures; 2) countries with antiquated or multi-tier system for registration of religious entities; 3) countries with state or established church; 4) French model, established with intention to control religion. ${ }^{14}$

Maurice Baribier used the concept of laicity (the constitutional separation of the church and state) to formulate a four-partite divide: secular state - France; quasi secular state - Italy, Spain, Portugal; semi secular state - Belgium, Germany, Ireland, Luxembourg, The Netherlands; and non secular state: Denmark, England, Greece. ${ }^{15}$

Mark Chaves and David E. Can have offered a more nuanced methodology. ${ }^{16}$ Although they still see the relationships between the church and the state one dimensionally, they study this dimension through six variables: 1) the existence of one recognized state church; 2) the existence of a number of denominations that are recognized by the state, while others are not; 3 ) the state is tasked with the initiation of the state officials; 4) the state pays the wages of the state officials; 5) the existence of taxation for the benefit of the church conducted by the state; 6 ) the state gives direct financial support for the church.

\footnotetext{
10 M. Minkenberg, 192

11 Concordatian system is in those states that have signed concordat with Vatican.

12 S. Ferrari 1995, 421.

13 Ibid, 421

14 M. Lavrič, S. Flere, "Divergent Trends in Legal Recognition of Religious Entities in Europe: The Cases of Slovenia and Hungary", Politics and Religion 2/2015, 286 304.

15 M. Minkenberg, 192.

16 Ibid, 193
} 
Summing up the values for each variable they reach a tripartite scheme: 1) full establishment church (Denmark, Finland, Norway, Sweden); 2) partial establishment (Austria, Spain, Portugal, Belgium, Germany, Great Britain, Italy, and Switzerland); 3) separation (Ireland, the Netherlands, France).

All of the models of the relationships between the church and the state presented up until this moment perceive this relationship one-dimensionally. In the passages below the views of the authors that perceive this relationship in two dimensions will be presented. Wait Bader analyzes two dimensions: establishment of religion and religious pluralism. The dimension of establishment is concerned with the institutionalization of one or more religions within a particular society so that there are constitutional, legal, administrative, political and cultural establishment. Pluralism is centrally concerned with the number of religious organization with which the state enters into a special relationship so that we can distinguish: monism, constitutional pluralism and strict separation. By combining constitutional formation and the type of pluralism Bader reaches a five-partite divide of the relationship between the church and religious organizations: 1) firmly established state church - Greece; 2) loosely established church - England and the Scandinavian states; 3) plural formation (constitutional pluralism) - The Netherlands, Belgium, Austria, Germany; 4) non constitutional pluralism of the state; 5) private pluralism USA. ${ }^{17}$

Although this classification seemingly uses two dimensions, in essence it is all about two variables that determine the same dimension. In addition to this, the depicted classification is very complex, insufficiently clarified and poor with regard to its applicability in practice. A more developed and adequate theoretical approach was given by D. Barett. ${ }^{18} \mathrm{He}$ perceived the relationship between the church and the state through two dimensions. The first dimension involved the religious character of the state so he divided the state in three groups according to this criterion: religious (where the majority belongs to a particular confession) secular and atheistic states.

Three criteria for the classification in one of these groups are: 1) the way the states see their relationship towards religious organization from formal and legal point of view in Constitutions, laws and programs of political parties; 2) to what extent the states are interested in religions or claim to have the right to interfere in religious issues; 3 ) to what extent these formally recognize accept religions and churches.

Within the second dimension Barrett perceives to what extent the state promotes, aids and limits the religion, so he classifies the states

\footnotetext{
17 V. Bader, 55-91

18 J. Madeley, 10-16
} 
within ten categories. The classification offered by Barrett is good, because it does not take into account only one dimension, but there are clear problems, theoretical and with regard to the classification of particular countries. Within the context of the dimension of the relationship of the state towards religious organizations for various positions there are different indicators. For some of these financial assistance is used as an indicator, whereas for others it is political and ideological relationship of the state towards religious organizations (support, denial of action, hostile attitude and repression). In the sense of the classification of various states in a specific field particular solutions are conspicuously questionable. Belgium and Slovenia are classified as religious states although they are not such according to their formal and legal organization, whilst Sweden is classified as a secular state according to the table for 2000, although the state enacted a specific law designed to enhance the relationship towards the church. Similarly FR Yugoslavia has been classified as an atheist country according to the data for the year 2000. Neither FR Yugoslavia, nor its republics have enacted constitutions and laws in the period 1991 to 2000 to limit neither religious freedoms of the religious communities nor the overall attitude of the state has been geared towards promoting atheism.

Javier Martinez-Torron and Cole Durham present a two dimensional model of the study of the relationship between the church and the state in various countries. The first dimension is centrally concerned with the position of religious organizations with regard to corporate freedoms and has two extremes: the absence of religious freedoms and the optimal religious freedoms. The second dimension studies neutrality of the state towards religious organizations. In the middle of the spectrum is the neutrality, that is to say, the non identification of the state with religious organizations. ${ }^{19}$ In essence this means that the state treats all of the religious organizations equally, and that they have the equal right to action. On one pole of the relationship is the state that actively supports religious freedoms of the religious organizations, and on the other pole it denies even the negative freedoms of religious organizations. When the graph that depicts this is connected with a curve, this curve has the U shape. Hence, ideal types of this relationship range from theocracy and state church, trough cooperation and secularism and towards the hostility and the prosecution of religion. Although interesting from a theological viewpoint, this classification is not appropriate for the study of the relationship between the church and religious organizations in the $21^{\text {st }}$ century, because all of the states except Vatican occupy a small part of the graph, which denies the possibility of further classification of such a relationship. Jonathan Fox has further developed Durham's classification scheme and applied it to the empirical study of separation of state and religion in 152

19 J. Martinez-Torron, C. Durham, 8-10. 
countries through four variables (which have a total of 60 components), for every year during 1990-2002 period. In the end, all countries were ranked on the ordinal scale into one of nine categories: 1. Established religion; 2. Multiple official religions; 3 . Civil religion; 4. Cooperation; 5. Supportive; 6. Accommodation; 7. Separationist; 8 . Inadvertent insensitivity; 9. Hostile. ${ }^{20}$

\section{AN ATTEMPT FOR THE DEVELOPMENT OF THE NEW THEORETICAL AND METHODOLOGICAL MODEL OF THE STUDY OF THE RELATIONSHIP BETWEEN THE STATE AND RELIGIOUS ORGANIZATIONS IN EUROPE}

At the very beginning the limitations of our research approach should be highlighted. In the first instance it is opportune to outline that the theoretical model that is depicted is focused on the analysis of the states with developed pluralism and democracy as a political system. Democratic political system within this context involves liberal (minimalist) view of democracy, and as the indispensable precondition for a political system to be classified as such we presuppose the existence of free, multiparty elections. According to the classification of the organisation Freedom House that would include free and partially free states. The stability of a free, democratic political system guarantees the relative stability of the legal and constitional order, and one part of the legal and constitutional order is a part that is under scrutiny in this investigation. On the other, by pluralist political system we understand that there is a freedom of expression of political viewpoints within a state, whether these are ideological, religious or philosophical.

The second part of limitations in the application of our theoretical and methodological model comes from our focus on states with overwhelmingly Christian religious tradition and population. In order for this model to be applicable to other states as well, some changes are necessary, that would be dependent on the specific characteristics of a particular religion. This expansion of the field of study will be the subject of further and more ambitious part of this research. Nevertheless, apart from the given shortcomings, it is clear that our model can be applied to other liberal and democratic states outside the European continent.

The considered analyses of the relation between the church and state examined within the last chapter differ from each as much with regard to their complexity, as with their theoretical approach, but they have in common that they depict this relationship in one dimension. Even those analyses, which have the authors that claim that they have adopted the

20 J. Fox, 537 
study in two dimensions are distinguished by intrinsic one dimensionality. Our interpretive frame starts from the supposition that there are two dimensions of separation in the domain of what the authors label as the relationship between the church and state. In that sense, it is important to separate the dimension that studies the relationships between states and concrete religious organisations from the dimension of relationship with religion as a system of beliefs, rituals, ethical precepts and worldviews. In order to clarify this, we will take into account two striking examples. The USA have, within their Constitution, and in the decisions of the constitutional court, adopted an approach that sees the strict separation of the state from religious organisations. On the other hand, the U.S. actively promote religion: The president gives an oath over the Holy Bible, the same situation is also in the courts, on the dollar note it reads "In God we trust" and so on. SFR Yugoslavia was the state that introduced, with the federal law enacted in 1976, strict separation of the state from religious organisations. At the same time the ruling ideology promoted atheism and was openly hostile to the public expression of religious object, except in religious objects and graveyards. Only with the analysis of the Contitution and court decisions we could classify both F.R. Yugoslavia and USA, using Barrett's scheme (religious-secular-atheist) as secular. Nonetheless, if we analyse the relationship of the state towards religion, we could classify the U.S. as religious and SFR Yugoslavia as atheist. With our theoretical approach we are trying to remove the shortcomings in the classification of all particular states (because the situation in all of the enumarated states does not correspond to the ideal types enumerated up until the present date).

Let us first start with the dimension of the relationship between the state and particular religious organisations. We will label this dimension as laicisation of the state. As we have hinted before, the separation of the state from the church has two separate dimensions - the state is divided from religious organisations and religious organisations are autonomous in their action. In addition to this, it is important to conceptually separate the equal treatment of religious organisations and the separation of religious organisations from the state. This in essence means that the state could be separated from religious organisations, but not neutral towards them. The best examples of both neutrality and separation of religious organisations towards the state can be seen within the U. S. context, where the conditions for the registration of religious organisation are the same as for the civic associations, and no religious organisation receives assistance from the state except for the tax brakes that is guaranteed to all of them and are the same for all of them. No state in Europe that we have studied so far, whose authority has been legally and constitutionally divided from that of the religious organisations, has been neutral towards religious organisations - either down to the inequality of the legal status 
or financial assistance provided to only some of the organisations. The second dimension, which we will label as secularization of the state ${ }^{21}$ refers to the promotion or the protection of religion by the state. While some religious organisations are in favour of the laicisation of the state (especially those that do not have the privileged status), no religious organisation can be expected not to promote religion, because it is the essence of their existence. Nonetheless, each state must decide whether or not it wants to promote the religious world views, be neutral or promote non religious views or atheism. The state safeguards religion through laws by denying the possibility of blasphemy, the laws that deny the possibility of verbal abuse of God or religion, or by the prohibiting promotion of atheism. ${ }^{22}$ European countries do not prohibit the public proclamation of atheism, but some have laws against the blasphemy, although they apply them rarely. Promotion of religion can be done in various ways: by organising catechism in public schools, by the request to give a public oath for some future incumbents or in courts, introduction of religious rituals in schools and public institutions, introduction of a number of religious holidays and so on. The absence of such measure of protection will be interpreted as the secularisation of the state.

\section{METHODOLOGY}

The goal of our empirical research has been to test to what extent our hypotheses can be applied to European countries. Our choice of countries to be studied has been guided by three criteria. The first criterion was to study the most populous countries of Europe. The second criterion was to involve countries with different traditions, those with the tradition of the state church, as well as those with the tradition of atheism or laicity (the former state socialist countries). The third criterion was the reliability of the available data. For each of the countries we read through articles in peer reviewed journals and book chapters that exclusively deal with the relationship between the state and religious organisations in these countries. At the very end we analyzed these countries: Albania, Belgium, Bulgaria, Denmark, France, Greece, The Netherlands, Croatia, Italy, Ger-

21 Complete literature and primary legal and constitutional documents that have been used in this research, as well as the data we have collected with variables for all of the countries, will not be presented here due to space constraints. The fulfillment of this condition would imply the process of writing up of a short monograph, and the form of monograph, rather than an article aimed at a peer reviewed journal. We believe that this fact does not lower the quality of the text, because according to the data in table 4. (where data for all of the countries are presented), and table 5 (where the key to the coding of primary data is given) it is possible to interpret the state of affairs for each country.

22 Some Islamic countries prohibit the open promotion of atheism, E. G. Iran, Egypt, Pakistan, Saudi Arabia and so on. 
many, Norway, Poland, Romania, Russia, Slovenia, Serbia, Spain, Sweden, Great Britain. These countries do not have the same internal political structure. Federal states give stronger discretionary rights to federal units in defining their relationship with religious organisations, while unitary states have the same regulatory framework for the whole territory. In that sense, Great Britain represents the biggest problem because of the complicated structure and the absence of a written constitution. In England the state religion is the Church of England, its head is the British monarch, in Scotland Church of Scotland is the national church, while Wales and Northern Ireland do not have official churches. In order for our data to be comparable in the case of the Great Britain, we concentrated on the regulatory framework that exists only in England. This is a shortcoming, but in the opposite case we would have to exclude Great Britain from this research, which is even more problematic a solution than the one we chose. Germany is a federal state where federal units have small sovereignity in regulating their relationship with religious organisations, but these are not of crucial importance for our research. France and Greece are specific among unitary states. In France, the law on the relationships between the church and state dates back to 1905. It is still in force, but this is not valid for Alsace and Loraine, that were not parts of France during its adoption, so that the data on France are not valid for those two particular territories. Greece gave specific discretionary power to the area of Trakia, and gives privileges to Muslim community that at the rest of the territory only has the orthodox majority ${ }^{23}$, so the data are valid for Greece without Trakia.

From the great number of areas that are regulated by the legal framework in these 19 countries, we focussed on a small number of them, and on those that we consider the most important, as well as those for which richest data are available. As the most important dimension for the laicisation of the state, following areas were analyzed and each one of these comes as an independent variable:

1. The existence of a constitionally determined official church;

2. Autonomy of the inner working of the church organisation;

3. Equality of legal status of religious organisations before the law;

4. Rigidity of registration of religious organisations;

5. The highest level of legal status that the most protected religious organisation has in each country;

6. Fiscal and financial relationship of the state towards religious organisations.

23 D. L. Selier, La vie politique des européen, Économica, Paris 1998. 
Studing the dimension of the secularization of the state has been guided by the following indicators:

1. If the state is legally and constitutionally bound to certain religions; ${ }^{24}$

2. The existence of the state protection of moral integrity of religious communities and religion;

3. The existence of prayer in public schools and institutions;

4. The number of religious holidays that a country has as state holidays;

5. The existence of religious symbols in public institutions;

6. The existence of religious education (catechism) in public schools;

7. The position of religious schools;

The presentation of variables for both dimensions can be found in the table 1 .

Table 1. Dimensions with variables

\begin{tabular}{|c|l|c|l|}
\hline Variable & Laicisation of the state & Variable & Secularisation of the state \\
\hline $\mathbf{A}$ & $\begin{array}{l}\text { Constitutionally founded } \\
\text { church }\end{array}$ & $\mathbf{G}$ & $\begin{array}{l}\text { If the state is constitutionally } \\
\text { or legally bound to a religion }\end{array}$ \\
\hline $\mathbf{B}$ & $\begin{array}{l}\text { Autonomy of internal action } \\
\text { of religious organisations - } \\
\text { government and parliament do } \\
\text { not make decisions that impact } \\
\text { the inner organisation and } \\
\text { functioning of the church }\end{array}$ & $\mathbf{H}$ & $\begin{array}{l}\text { The protection of moral in- } \\
\text { tegrity }\end{array}$ \\
\hline $\mathbf{C}$ & $\begin{array}{l}\text { Equality of the legal state of } \\
\text { religious organisations - } \\
\text { number of legal levels }\end{array}$ & $\mathbf{I}$ & $\begin{array}{l}\text { Prayers in public schools and } \\
\text { institutions }\end{array}$ \\
\hline $\mathbf{D}$ & $\begin{array}{l}\text { Rigidity in registration of } \\
\text { religious organisations }\end{array}$ & $\mathbf{J}$ & $\begin{array}{l}\text { Religious holidays as state } \\
\text { holidays }\end{array}$ \\
\hline $\mathbf{E}$ & $\begin{array}{l}\text { The highest level that the most } \\
\text { privileged religious organisa- } \\
\text { tion has }\end{array}$ & $\mathbf{K}$ & $\begin{array}{l}\text { Religious symbols in public } \\
\text { institutions }\end{array}$ \\
\hline
\end{tabular}

24 The difference between the variable 1 in first dimension and variable 1 in the second dimension is that variable 1 in first dimension refers to the connection of the state to particular religious organization, while the other refers to the connection of the state with religion as a system of beliefs. 
Annals FLB - Belgrade Law Review, Year LXIV, 2016, No. 3

\begin{tabular}{|c|l|c|l|}
\hline Variable & Laicisation of the state & Variable & Secularisation of the state \\
\hline $\mathbf{F}$ & $\begin{array}{l}\text { Fiscal and financial relation- } \\
\text { ship between the state and re- } \\
\text { ligious organisations }\end{array}$ & $\mathbf{L}$ & $\begin{array}{l}\text { Religious instruction in public } \\
\text { schools }\end{array}$ \\
\hline & M & $\begin{array}{l}\text { The status of religious } \\
\text { schools }\end{array}$ \\
\hline
\end{tabular}

After the data collection from predetermined areas we decided to ascribe quantitative value to qualitative data as follows. This can be found in table 2.

Table 2. Variables, solutions for variables and ascribed numerical values

\begin{tabular}{|c|c|c|c|}
\hline $\begin{array}{l}\text { Ascription } \\
\text { of value to } \\
\text { variable }\end{array}$ & Variable & Solution to the variable & N1 \\
\hline \multirow[t]{3}{*}{ A } & $\begin{array}{l}\text { Constitutionally established } \\
\text { church }\end{array}$ & State church & 1 \\
\hline & & $\begin{array}{l}\text { National, traditional and popular } \\
\text { church }\end{array}$ & 2 \\
\hline & & $\begin{array}{l}\text { There is no mentioning of reli- } \\
\text { gion within the constitution, ex- } \\
\text { cept to the guarantee of religious } \\
\text { freedoms }\end{array}$ & 3 \\
\hline \multirow[t]{3}{*}{ B } & $\begin{array}{l}\text { Autonomy of the inner working of } \\
\text { church organisations, the govern- } \\
\text { ment and churches do not make } \\
\text { decisions that impact the inner } \\
\text { working of religious organisations }\end{array}$ & $\begin{array}{l}\text { Church law forms the part of the } \\
\text { legal system of the country, con- } \\
\text { stitution is enacted by the par- } \\
\text { liament, church officials are ap- } \\
\text { pointed by the state (monarch, } \\
\text { president, government of the } \\
\text { parliament) }\end{array}$ & 1 \\
\hline & & $\begin{array}{l}\text { Church law does not represent a } \\
\text { part of the legal system of a state, } \\
\text { parliament issues the church con- } \\
\text { stitution, church officials are ap- } \\
\text { pointed by the state }\end{array}$ & \\
\hline & & $\begin{array}{l}\text { Church law does not constitute } \\
\text { a part of the legal system of the } \\
\text { country, the church constitution } \\
\text { is not enacted by the parliament, } \\
\text { the most important church offi- } \\
\text { cials are appointed by the state }\end{array}$ & 3 \\
\hline
\end{tabular}


Velizar Mirčov, Ivica Mladenović (p. 241-265)

\begin{tabular}{|c|c|c|c|}
\hline \multirow{2}{*}{$\begin{array}{l}\text { Ascription } \\
\text { of value to } \\
\text { variable }\end{array}$} & Variable & Solution to the variable & $\mathrm{N} 1$ \\
\hline & & $\begin{array}{l}\text { Church law is not a part of the } \\
\text { legal system of the country, the } \\
\text { constitution of the church is not } \\
\text { enacted by the parliament, reli- } \\
\text { gious organisations are inde- } \\
\text { pendent in the appointment of } \\
\text { their officials }\end{array}$ & 4 \\
\hline \multirow[t]{3}{*}{$\mathrm{C}$} & $\begin{array}{l}\text { Equality of legal position of reli- } \\
\text { gious organisations - a number of } \\
\text { levels of legal solutions }\end{array}$ & $\begin{array}{l}\text { There are more than two levels } \\
\text { of legal status of religious or- } \\
\text { ganisations and each lavel has } \\
\text { diferent rights and privileges }\end{array}$ & 1 \\
\hline & & $\begin{array}{l}\text { There are two levels of legal } \\
\text { status of religious organisations } \\
\text { where one has stronger privi- } \\
\text { leges than other }\end{array}$ & 2 \\
\hline & & $\begin{array}{l}\text { All registered religious organi- } \\
\text { sations have the same rights }\end{array}$ & 3 \\
\hline \multirow[t]{3}{*}{$\mathrm{D}$} & $\begin{array}{l}\text { Rigidity in registration of religious } \\
\text { organisations }\end{array}$ & $\begin{array}{l}\text { Registered religious organiza- } \\
\text { tions must fulfill strict condi- } \\
\text { tions or sign a special conctract } \\
\text { with a state }\end{array}$ & 1 \\
\hline & & $\begin{array}{l}\text { Registered religious organisa- } \\
\text { tions must have } 100 \text { members } \\
\text { and exist for } 10 \text { years, or there } \\
\text { are clear hindrances to registra- } \\
\text { tion although they fulfill other } \\
\text { conditions }\end{array}$ & 2 \\
\hline & & $\begin{array}{l}\text { The conditions for registrations } \\
\text { are liberal and most of the or- } \\
\text { ganisations pass the process of } \\
\text { registration }\end{array}$ & 3 \\
\hline \multirow[t]{3}{*}{$\mathrm{E}$} & $\begin{array}{l}\text { The highest level that the most } \\
\text { privileged organisation has }\end{array}$ & $\begin{array}{l}\text { State, national or privileged } \\
\text { church }\end{array}$ & 1 \\
\hline & & $\begin{array}{l}\text { One or more churches that the } \\
\text { state provides guarantee by con- } \\
\text { stitution and law for financial } \\
\text { assistance, especially with re- } \\
\text { gard to catechism }\end{array}$ & 2 \\
\hline & & $\begin{array}{l}\text { Registered religious organisa- } \\
\text { tion has privileges apart from } \\
\text { tax brakes }\end{array}$ & 3 \\
\hline
\end{tabular}


Annals FLB - Belgrade Law Review, Year LXIV, 2016, No. 3

\begin{tabular}{|c|c|c|c|}
\hline \multirow{2}{*}{$\begin{array}{l}\text { Ascription } \\
\text { of value to } \\
\text { variable }\end{array}$} & Variable & Solution to the variable & $\mathrm{N} 1$ \\
\hline & & $\begin{array}{l}\text { Registered religious organisa- } \\
\text { tion's only privilege is the tax } \\
\text { brakes }\end{array}$ & 4 \\
\hline \multirow[t]{4}{*}{$\mathrm{F}$} & $\begin{array}{l}\text { Fiscal and financial relationship } \\
\text { between the state and religious or- } \\
\text { ganisations }\end{array}$ & $\begin{array}{l}\text { The state is bound by law or the } \\
\text { Constitution to finance only one } \\
\text { religious organisation }\end{array}$ & 1 \\
\hline & & $\begin{array}{l}\text { The state finances and offers tax } \\
\text { brakes for two or more of the } \\
\text { privileged religious organisa- } \\
\text { tions }\end{array}$ & 2 \\
\hline & & $\begin{array}{l}\text { The state finances all of the reli- } \\
\text { gious organisations proportion- } \\
\text { ally }\end{array}$ & 3 \\
\hline & & $\begin{array}{l}\text { The state gives tax exemption to } \\
\text { all of the religious organisation } \\
\text { but does not finance their work }\end{array}$ & 4 \\
\hline \multirow[t]{4}{*}{ G } & $\begin{array}{l}\text { Whether the state is legally or con- } \\
\text { stitutionally bound to specific reli- } \\
\text { gion }\end{array}$ & $\begin{array}{l}\text { The constitution establishes na- } \\
\text { tional or traditional religion }\end{array}$ & 1 \\
\hline & & $\begin{array}{l}\text { Some religions have traditional } \\
\text { status by the law }\end{array}$ & 2 \\
\hline & & $\begin{array}{l}\text { The constitution calls on God or } \\
\text { Holy Trinity }\end{array}$ & 3 \\
\hline & & $\begin{array}{l}\text { The Constitution and laws do } \\
\text { not recognize any religion as } \\
\text { national or traditional }\end{array}$ & 4 \\
\hline \multirow[t]{4}{*}{$\mathrm{H}$} & The protection of moral integrity & $\begin{array}{l}\text { There are laws against blasphe- } \\
\text { my for only one organisation } \\
\text { and these are being applied }\end{array}$ & 1 \\
\hline & & $\begin{array}{l}\text { There are laws against blasphe- } \\
\text { my for only one organisation } \\
\text { and these are not being applied }\end{array}$ & 2 \\
\hline & & $\begin{array}{l}\text { There are laws against blasphe- } \\
\text { my for all of the organisations } \\
\text { or against God }\end{array}$ & 3 \\
\hline & & $\begin{array}{l}\text { There are only laws against the } \\
\text { spread of religious hatred }\end{array}$ & 4 \\
\hline
\end{tabular}


Velizar Mirčov, Ivica Mladenović (p. 241-265)

\begin{tabular}{|c|c|c|c|}
\hline $\begin{array}{l}\text { Ascription } \\
\text { of value to } \\
\text { variable }\end{array}$ & Variable & Solution to the variable & $\mathrm{N} 1$ \\
\hline \multirow[t]{4}{*}{ I } & $\begin{array}{l}\text { Prayer in public schools and insti- } \\
\text { tutions }\end{array}$ & $\begin{array}{l}\text { The prayer is compulsory in all } \\
\text { schools and Parliament }\end{array}$ & 1 \\
\hline & & $\begin{array}{l}\text { Prayer is complusory in schools } \\
\text { but not in state institutions }\end{array}$ & 2 \\
\hline & & $\begin{array}{l}\text { The prayer is allowed in } \\
\text { schools }\end{array}$ & 3 \\
\hline & & $\begin{array}{l}\text { Prayer is prohibited in schools } \\
\text { and state institutions }\end{array}$ & 4 \\
\hline \multirow[t]{4}{*}{$\mathrm{J}$} & $\begin{array}{l}\text { Religious holidays as state holi- } \\
\text { days }\end{array}$ & $\begin{array}{l}\text { Number of religious holidays } \\
\text { passes } 10\end{array}$ & 1 \\
\hline & & $\begin{array}{l}\text { Number of religious holidays is } \\
6-10\end{array}$ & 2 \\
\hline & & $\begin{array}{l}\text { Number of religious holidays is } \\
3-5\end{array}$ & 3 \\
\hline & & $\begin{array}{l}\text { Number of religious holidays is } \\
1-2\end{array}$ & 4 \\
\hline \multirow[t]{4}{*}{ K } & $\begin{array}{l}\text { Religious symbols in public insti- } \\
\text { tutions }\end{array}$ & $\begin{array}{l}\text { Religious symbols (cross, cruci- } \\
\text { fixion, icons and etc.) must be } \\
\text { exposed in public institutions } \\
\text { and schools }\end{array}$ & 1 \\
\hline & & $\begin{array}{l}\text { Religious symbols can be ex- } \\
\text { posed in public institutions and } \\
\text { schools }\end{array}$ & 2 \\
\hline & & $\begin{array}{l}\text { Religious symbols can not be } \\
\text { exposed in schools but can be in } \\
\text { state institutions }\end{array}$ & 3 \\
\hline & & $\begin{array}{l}\text { Religious symbols can not be } \\
\text { exposed in state institutions and } \\
\text { schools }\end{array}$ & 4 \\
\hline \multirow[t]{3}{*}{$\mathrm{L}$} & Catechism in public schools & $\begin{array}{l}\text { Catechism is compulsory and is } \\
\text { theological in character }\end{array}$ & 1 \\
\hline & & $\begin{array}{l}\text { Catechism is compulsory and } \\
\text { theological but pupils can be ex- } \\
\text { empted from attendance }\end{array}$ & 2 \\
\hline & & $\begin{array}{l}\text { Catechism or religiologius edu- } \\
\text { cation is compulsury, and one } \\
\text { must be chosen }\end{array}$ & 3 \\
\hline
\end{tabular}


Annals FLB - Belgrade Law Review, Year LXIV, 2016, No. 3

\begin{tabular}{|c|l|l|c|}
\hline $\begin{array}{l}\text { Ascription } \\
\text { of value to } \\
\text { variable }\end{array}$ & Variable & Solution to the variable & N1 \\
\hline & & $\begin{array}{l}\text { Religious education or alternate } \\
\text { study program (secular, human- } \\
\text { istic or civic in type) is compul- } \\
\text { sory and one must be chosen }\end{array}$ & 4 \\
\hline & $\begin{array}{l}\text { Religious education is optional } \\
\text { but is a part of public schools }\end{array}$ & 5 \\
\hline M position of religious schools & $\begin{array}{l}\text { There is no religious education } \\
\text { in public schools }\end{array}$ & 6 \\
\hline & and are financed by the state & 2 \\
\hline & $\begin{array}{l}\text { Private religious schools exist } \\
\text { but are not financed by the state }\end{array}$ & 4 \\
\hline
\end{tabular}

After codification of the solution for each particular variable, for all the states, we ascribed numerical value for each variable and state, and the results obtained are displayed in table 3 .

Table 3. The display of variables for each state

\begin{tabular}{|l|c|c|c|c|c|c|c|c|c|c|c|c|c|c|}
\hline & A & B & C & D & E & F & G & H & I & J & K & L & M & SUM $^{25}$ \\
\hline ALB $^{26}$ & 3 & 4 & 2 & 3 & 2 & 4 & 3 & 4 & 4 & 3 & 4 & 6 & 4 & 46 \\
\hline RUS & 3 & 4 & 1 & 3 & 2 & 2 & 2 & 3 & 4 & 4 & 4 & 4 & 4 & 40 \\
\hline GER & 3 & 4 & 2 & 2 & 2 & 2 & 3 & 3 & 1 & 4 & 2 & 4 & 2 & 34 \\
\hline GBR & 1 & 1 & 2 & 3 & 1 & 2 & 1 & 4 & 2 & 3 & 3 & 4 & 2 & 29 \\
\hline ITA & 3 & 4 & 2 & 1 & 2 & 2 & 4 & 3 & 3 & 2 & 1 & 2 & 2 & 31 \\
\hline ESP & 3 & 4 & 1 & 1 & 2 & 2 & 4 & 3 & 3 & 2 & 2 & 3 & 2 & 32 \\
\hline FRA & 3 & 4 & 2 & 2 & 4 & 2 & 4 & 4 & 4 & 3 & 4 & 6 & 2 & 44 \\
\hline POL & 3 & 4 & 2 & 2 & 3 & 1 & 3 & 3 & 2 & 1 & 1 & 4 & 2 & 31 \\
\hline ROU & 3 & 4 & 1 & 2 & 2 & 2 & 4 & 4 & 4 & 2 & 2 & 2 & 2 & 34 \\
\hline NLD & 3 & 4 & 3 & 3 & 4 & 3 & 4 & 4 & 1 & 3 & 2 & 4 & 2 & 40 \\
\hline
\end{tabular}

25 The column sum's only purpose is to give a sum of values and has no other theoretical or empirical significance.

26 From purely technical reasons, we list only the three-lettered abbreviations of the countries listed in the table. 


\begin{tabular}{|l|c|c|c|c|c|c|c|c|c|c|c|c|c|c|}
\hline BEL & 3 & 4 & 2 & 1 & 2 & 2 & 4 & 4 & 4 & 2 & 3 & 4 & 2 & 37 \\
\hline GRC & 2 & 1 & 2 & 1 & 1 & 2 & 1 & 1 & 1 & 2 & 1 & 1 & 2 & 18 \\
\hline SWE & 1 & 1 & 2 & 3 & 1 & 3 & 2 & 4 & 4 & 2 & 4 & 4 & 2 & 33 \\
\hline BGR & 2 & 4 & 2 & 3 & 1 & 3 & 1 & 4 & 4 & 3 & 4 & 5 & 4 & 40 \\
\hline SRB & 3 & 4 & 2 & 2 & 1 & 2 & 2 & 4 & 3 & 3 & 2 & 4 & 4 & 36 \\
\hline DNK & 1 & 1 & 2 & 3 & 1 & 1 & 1 & 2 & 1 & 1 & 4 & 2 & 2 & 22 \\
\hline SVK & 3 & 4 & 2 & 2 & 2 & 3 & 4 & 4 & 4 & 2 & 4 & 6 & 4 & 44 \\
\hline NOR & 2 & 4 & 2 & 3 & 1 & 3 & 1 & 2 & 3 & 2 & 4 & 3 & 4 & 34 \\
\hline HRV & 3 & 4 & 1 & 2 & 2 & 2 & 4 & 4 & 3 & 2 & 2 & 5 & 2 & 36 \\
\hline
\end{tabular}

After this for each variable three subdimensions have been made. Variables A and B, if merged, form the subdimension of laicisation of legal system; Variables C, D and E are the subdimension of equality of the legal status of religious organisations whilst the subdimension $\mathrm{F}$ forms the subdimension of neutrality of the state. Dimension of secularization is divided into three subdimensions: variables $\mathrm{G}$ and $\mathrm{H}$ constitute the subdimension of the protection of religion, I, J and $\mathrm{K}$ constitute subdimension of public religious symbolism, and $\mathrm{L}$ and $\mathrm{M}$ constitute the subdimension of promotion of religious education.

We have conducted the addition of numerical values for each particular country. On the basis of this addition each country has been ascribed numerical value for each subdimension. For each subdimension the values ranged from one to four, whereby one meant the least pronounced secularisation/ laicisation, and four the most pronounced. A1though the number was different for each particular variable, this proces simplified the coding of data. The proces of ascription of values has been explained in the table 4 .

Table 4. Key to the ascription of variables

\begin{tabular}{|l|l|l|l|l|}
\hline $\begin{array}{l}\text { Ascribed value to } \\
\text { the subdimension }\end{array}$ & \multicolumn{1}{|c|}{1} & \multicolumn{1}{|c|}{3} & \multicolumn{1}{|c|}{4} \\
\hline $\begin{array}{l}\text { Laicisation of } \\
\text { constitutional and } \\
\text { legal system }\end{array}$ & $\begin{array}{l}\text { Sum of } \\
\text { variables 2 }\end{array}$ & $\begin{array}{l}\text { Sum of } \\
\text { variables 3 to 4 }\end{array}$ & $\begin{array}{l}\text { Sum of } \\
\text { variables 4 to 6 }\end{array}$ & $\begin{array}{l}\text { Sum of } \\
\text { variables 7 }\end{array}$ \\
\hline $\begin{array}{l}\text { Equality of the } \\
\text { legal position of } \\
\text { religious } \\
\text { organisations }\end{array}$ & $\begin{array}{l}\text { Sum of } \\
\text { variables 3 }\end{array}$ & $\begin{array}{l}\text { Sum of } \\
\text { variables 4 to 6 }\end{array}$ & $\begin{array}{l}\text { Sum of } \\
\text { variables 7 to 9 }\end{array}$ & $\begin{array}{l}\text { Sum of } \\
\text { Variables 10 }\end{array}$ \\
\hline
\end{tabular}


Annals FLB - Belgrade Law Review, Year LXIV, 2016, No. 3

\begin{tabular}{|l|l|l|l|l|}
\hline $\begin{array}{l}\text { Ascribed value to } \\
\text { the subdimension }\end{array}$ & \multicolumn{1}{|c|}{1} & \multicolumn{1}{|c|}{2} & \multicolumn{1}{|c|}{4} \\
\hline $\begin{array}{l}\text { Economic neutrali- } \\
\text { ty of the country }\end{array}$ & $\begin{array}{l}\text { Sum of } \\
\text { variables 1 }\end{array}$ & $\begin{array}{l}\text { Sum of } \\
\text { variables 2 }\end{array}$ & $\begin{array}{l}\text { Sum of } \\
\text { variables 3 }\end{array}$ & $\begin{array}{l}\text { Sum of } \\
\text { variables 4 }\end{array}$ \\
\hline $\begin{array}{l}\text { Protection of } \\
\text { religion }\end{array}$ & $\begin{array}{l}\text { Sum of } \\
\text { variables 2 }\end{array}$ & $\begin{array}{l}\text { Sum of } \\
\text { variables 3 to 4 }\end{array}$ & $\begin{array}{l}\text { Sum of } \\
\text { variables 5 to 7 }\end{array}$ & $\begin{array}{l}\text { Sum of } \\
\text { variables 8 }\end{array}$ \\
\hline $\begin{array}{l}\text { Public religious } \\
\text { symbolism }\end{array}$ & $\begin{array}{l}\text { Sum of } \\
\text { variables } 3\end{array}$ & $\begin{array}{l}\text { Sum of } \\
\text { variables 4 to 7 }\end{array}$ & $\begin{array}{l}\text { Sum of } \\
\text { variables 8 to 10 }\end{array}$ & $\begin{array}{l}\text { Sum of } \\
\text { variables 11 }\end{array}$ \\
\hline $\begin{array}{l}\text { Promotion of reli- } \\
\text { gious education }\end{array}$ & $\begin{array}{l}\text { Sum of } \\
\text { variables 3 }\end{array}$ & $\begin{array}{l}\text { Sum of } \\
\text { variables 4 to 6 }\end{array}$ & $\begin{array}{l}\text { Sum of } \\
\text { variables 7 to 9 }\end{array}$ & $\begin{array}{l}\text { Sum of } \\
\text { variables 10 }\end{array}$ \\
\hline
\end{tabular}

After the ascription of numerical values for subdimensions for each country, for each country we have done addition so that we could get final values for each country and subdimension. For each country, the range of possible values went from 3 (the least pronounced characteristic) to 12 (the most pronounced characteristic). Values are given in table 5.

Table 5 . The values of dimension for each country.

\begin{tabular}{|l|c|c|}
\hline & Laicisation & Secularisation \\
\hline ALB & 11 & 11 \\
\hline RUS & 9 & 9 \\
\hline GER & 9 & 7 \\
\hline GRB & 6 & 8 \\
\hline ITA & 8 & 7 \\
\hline SPA & 8 & 7 \\
\hline FRA & 9 & 12 \\
\hline POL & 8 & 7 \\
\hline ROU & 8 & 9 \\
\hline NDL & 11 & 8 \\
\hline BEL & 8 & 9 \\
\hline GRE & 7 & 4 \\
\hline SWE & 9 & 8 \\
\hline BLG & 8 & 10 \\
\hline SRB & 5 & 6 \\
\hline DEN & 6 & \\
\hline
\end{tabular}




\begin{tabular}{|l|c|c|}
\hline SLO & 10 & 11 \\
\hline NOR & 8 & 8 \\
\hline CRO & 8 & 9 \\
\hline
\end{tabular}

At the end there is a final table. Within the dimension of laicisation the lowest value is 5, so with this in mind we formed the categories for this dimension: the state is not laicised - sum 5 to 6; partially laicised state - sum 7 to 8 ; the laicisation of the state is pronounced - sum 9 to 10; fully laicized state - sum 11 to 12 . Within the dimension of secularisation the categories are formed as follows: non-secularized state - sum 3 to 4; partially non-secularized state - sum 5 to 7; partially secularized state - sum 8 to 10 ; fully secularized state - sum 11 to 12 :. The position of each country when the categories are cross-tabulated is shown in table 6.

Table 6. Position of European countries with regard to secularization and laicization of the state

\begin{tabular}{|c|c|c|c|c|}
\hline & $\begin{array}{l}\text { The state is } \\
\text { not laicized }\end{array}$ & $\begin{array}{l}\text { Partially } \\
\text { laicized state }\end{array}$ & $\begin{array}{l}\text { The laicization } \\
\text { of the state is } \\
\text { pronounced }\end{array}$ & $\begin{array}{l}\text { Fully } \\
\text { laicized state }\end{array}$ \\
\hline $\begin{array}{l}\text { Non-secularized } \\
\text { state }\end{array}$ & Greece & & & \\
\hline $\begin{array}{l}\text { Partially } \\
\text { non-secularized } \\
\text { state }\end{array}$ & Denmark & $\begin{array}{l}\text { Italy, Spain, } \\
\text { Poland }\end{array}$ & Germany & \\
\hline $\begin{array}{l}\text { Partially } \\
\text { secularized state }\end{array}$ & Great Britain & $\begin{array}{l}\text { Sweden, } \\
\text { Romania, } \\
\text { Belgium, } \\
\text { Serbia, } \\
\text { Norway, } \\
\text { Croatia }\end{array}$ & $\begin{array}{l}\text { Russia, } \\
\text { Bulgaria }\end{array}$ & Netherlands \\
\hline $\begin{array}{l}\text { Fully } \\
\text { secularized state }\end{array}$ & & & $\begin{array}{l}\text { France, } \\
\text { Slovenia }\end{array}$ & Albania \\
\hline
\end{tabular}

\section{CONCLUSION}

With the development of our theoretical and methodological approach we have developed a classificatory scheme which, when two dimensions are cross-tabulated, gives 16 ideal types. Some of these types do not exist in actual reality (when the state is not laicized, but is secularizated, or when the state is fully laicized but is insufficiently secular- 
ized). After an inquiry into the legislative of 19 countries they are classified in 10 fields out of possible 16. If we included in our inquiry other 30 remaining states of Europe, perhaps some empty boxes in the table would be filled. Nonetheless, these boxes are found on the bottom left and top right corner and this indicates that studied characteristics (laicization and secularization of the state) are not independent from each other.

Our theoretical stance has not been that these two characteristics are independent, but that they need to be investigated separately, and by different variables. ${ }^{27}$ The advantage of our approach is that there are clear and verifiable indicators through which variables are measured, which enables easy and outright positioning on the table of each country.

A great majority of the states under scrutiny in this research have changed their legislative with regard to the state and church law. Italy (1984), Sweden (2000) and Norway (2012) have made state churches defunct; Russia, Poland, Albania, Croatia, Serbia, Slovenia, Bulgaria and Romania have become parliamentary democracies, they have abandoned their atheist approach, and have en block adopted legal solutions that correspond to the concept of cooperative separation of the state and religious organisations. Cooperative separation is indeed the ideological concept for the great majority of the studied states (except Greece and Albania). Nonetheless, this expression, that best describes practice and goals of the majority of European states, is insufficiently precise. On the one hand, it does not make apparent which type of cooperation we have in question, which are the areas of cooperation and which purpose we have in mind (every cooperation has a purpose). On the other hand, it is not apparent which areas the concept of separation refers to.

There are many advantages of this theoretical and methodological approach. It is applicable to many countries in the Europe and the world, it has clearly defined variables and indicators by which the intensity of both dimensions are measured, enabling easy and clear positioning of each state. As has been indicated earlier, although the two dimensionslaicism and secularism-are intimately interlinked, they need to be studied separately, because in the opposite case, as is the case with schemes with one dimension, it is not possible to separate the subtleties and differences that exist with legal solutions for each of the dimensions for the European states.

27 Pearson's coefficient of correlation for these two dimensions for 19 states is 0,66 which means moderately strong correlation and makes the independent study of these two dimensions justifiable. 


\section{REFERENCES}

Alibašić A. (ed.), Religija i sekularna država, Foundation Konrad Adenauer, Sarajevo 2008.

Alibašić A., "Modeli uređenja odnosa između države i vjerskih zajednica u Evropi i SAD-u i njihove konsekvence", Religija i sekularna država (ed. A. Ahmet), Foundation Konrad Adenauer, Sarajevo 2008.

Avramović S., Prilozi nastanku državno-crkvenog prava u Srbiji, Službeni glasnik, Beograd 2007.

Bader V., "Religions and States. A New Typology and a Plea for NonConstitutional Pluralism", Ethical Theory and Moral Practice 6/2003, 55-91.

B. Basdevant-Gaudemet, F. Messner, (dir.), Les origines historiques $d u$ statut des confessions religieuses dans les pays de l'Union européenne, Presses Universitaires de France, Paris 1999.

Baubérot, J., Laïcité 1905-2005, entre passion et raison. Seuil, Paris 2004.

Beaufor, F., Separation of Church and State in Europe,: European Liberal Forum, Brussels 2008.

Blagojević, M., Religija i crkva u transformacijama društva (Religion and church within societal transformations), Institute for Philosophy and Social Theory, Belgrade 2005.

Casanova, J., "Rethinking Secularization: A Global Comparative Perspective". The Hedgehog Review, 8(1-2)/2006.

Chaves, M., Cann, D. E., "Regulation, Pluralism, and Religious Market Structure. Explaining Religion's Vitality", Rationality and Society, 4/3/1992.

Chaves, M., P. S. Gorski, "Religious Pluralism and Religious Participation", Annual Review of Sociology 27/2001.

Cranmer, F., "Notes on Church and State in the European Economic Area 2011", $\quad$ http://www.law.cf.ac.uk/clr/networks/Frank\%20Cranmer_\%20Church\%20\&\%20State\%20 in\%20 W\%20Europe.pdf, last visited 15 March 2014.

Ferrari, S., "Separation of Church and State in Contemporary European Society", Journal of Church and State 30(3)/1988.

Ferrari, S., "The Emerging Pattern of Church and State in Western Europe: The Italian Model", BYU Law Review 2/1995.

Francis, J., "The Evolving Regulatory Structure of European ChurchState Relationships", Journal of Church and State 1992.

Fox, J., "World Separation of Religion and State In to the 21st Century", Comparative Political Studies 5/2006. 
Hamburger, P., Separation of Church and State, Harvard University Press, Cambridge 2002.

Kalkandjieva, D., "A Comparative Analysis on Church-State Relations in Eastern Orthodoxy: Concepts, Models, and Principles", Journal of Church and State 53(4)/2011.

Lavrič, M., Flere, S. "Divergent Trends in Legal Recognition of Religious Entities in Europe: The Cases of Slovenia and Hungary", Politics and Religion 2/2015.

Madeley, J. (ed), Church and State in Contemporary Europe, Frank Cass, London 2005a.

Madeley, J., "European Liberal Democracy and the Principle of State Religious Neutrality", Church and State in Contemporary Europe (ed. J. Madeley), Frank Cass, London 2005b.

Madeley, J., "A Framework for the Comparative Analysis of Church-State Relations in Europe", Church and State in Contemporary Europe (ed. J. Madeley), Frank Cass, London 2005c.

Manuel, P. C. (ed.), The Catholic Church and the Nation-State Comparative Perspectives, Georgetown University Press, Washington 2007.

Martinez-Torron, J., Durham, C., "Religion and the Secular State / La Religion et l'État laïque: Interim Reports, General Rapporteurs", Religion and the Secular State / La Religion et l'État laïque: Interim Reports (Durham, C ed.), International Center for Law and Religion Studies 2010.

Minkenberg, M., "The Policy Impact of Church-State Relations: Family Policy and Abortion in Britain, France, and Germany", Church and State in Contemporary Europe (ed. J. Madeley) Frank Cass, London 2005.

Monod, J., Sécularisation et laïcité, Presses Universitaires de France, Paris 2007.

Monsma, S., Soper, C., The Chellenge of Pluralism, Rowman \& Littlefield Publishers, inc, Lanhman 2009.

Norris, P., Inglehart, R., Sacred and Secular: Religion and Politics Worlwide, Harvard University Press, Harvard 20112.

Radulović, M., Obnova srpskog državno-crkvenog prava, Foundation Konrad Adenauer, Belgrade 2009.

Remond, R., Religion et société en Europe: La sécularisation aux XIX et XX siècles 1789- 2000, Seuil, Paris 2001.

Riis, O., "State Churches", The Encyclopedia of Politics and Religion, 2 vols (ed. R. Wuthnow) Routledge, London 1988.

Selier, D., La vie politique des européen, Économica, Paris 1998. 
Stepan, A., "The Multiple Secularism of Modern Democratic and NonDemocratic Regimes", Rethinkins Secularism, (ed. C. Calhoun), Oxford University Press, New York 2011.

Šijaković, B. (ed.), Pravni položaj crkava i vjerskih zajednica u Crnoj Gori danas, BONAFIDES, Nikšić 2009.

Vukomanović, M., Religija, Zavod za udžbenike i nastavna sredstva, Beograd 2004. 